\title{
OOR DIE TWEEDE VATIKAANKONSILIE ${ }^{1)}$
}

Een van die merkwaardigste figure wat in die moderne tyd pous van Rome was, was ongetwyfeld Angelo Roncalli wat in 1958 op 76-jarige leeftyd as Johannes XXIII pous van Rome geword het. Dit was in 1958 feitlik algemeen aangeneem dat hierdie man as 'n „,oorgangspous" gekies is, 'n pous wat slegs enkele jare sou regeer en wat 'n verademing sou skep na die langdurige en taamlike outokratiese regering van pous Pius XII. Hierdie pous Pius XII was self óók 'n merkwaardige figuur teruggetrokke, streng asketies en moeilik benaderbaar. 'n Pous wat ' $n$ afstand geskep het tussen homself, as hoogste kerkvors en die kerk, 'n man wat met vaste hand die kerk gelei het, egter dikwels op só 'n manier dat die roomse kerk die indruk geskep het dat dit 'n geslote bolwerk is, 'n on-inneembare fort wat op verdediging ingestel is. In die wêreld weliswaar maar afgeslote, gedistansieer van die wêreld. Johannes XXIII, volgens die beskikbare getuienisse oor hom, was heeltemal anders. 'n Man met 'n ruim oop gees, breed van uitsig op die wêreld. Nie alleen binne-kerklik nic maar ook na die wêreld toe het hy die roomse kerk gelei na 'n nuwe openheid en openhartigheid wat die roomse kerk in baic jare nié gehad het nie. Dit was die wens van Johannes XXIII dat die roomse kerk weer dinamies in die wêreld moct wees en hy het geoordeel dat daarvoor ook 'n hernuwing van die roomse kerk self nodig was en is ${ }^{2}$ ). Op verskillende maniere het Johannes XXIII getrag om die roomse kerk die groter openheid te gee.

In die eerste plek het hy 'n roomse, ekumeniese konsilie, wat as die Tweede Vatikaanse konsilie in die geskiedenisboeke bekend sal staan, byeengerocp. Die moontlikheid om 'n konsilie te hou was vir baie jare in die roomse kerk ' $\mathrm{n}$ vreemde gedagte. Die sterk gesentraliseerde regering van dic roomse wêreldkerk in die Vatikaan, het dit as onnodig beskou om die 2,500 biskoppe van die roomse kerk saam te laat vergader, ook al omdat, volgens roomse opvattings, die opvattings en besluite van so 'n konsilie alleen in die kerk gesag het as dit deur dic pous bckragtig word. Immers die pous is die onfeilbare plaasvervanger van Christus op aarde en hy het in die roomse kerk altyd die laaste woord. Tog het Johannes XXIII 'n konsilie laat byeenkom en dit on 11 Oktober 1962 formeel geopen om sodoende die biskoppe van die kerk byeen te bring, 'n gesprek tussen die verskillende teologiese rigtings in die kerk op gang te bring alles met die doel om 'n nuwe openheid in die kerk te skep en ook om vernuwings in die kerk te bring.

In die tweede plek het die pous getrag om deur middel van sy herderlike skrywes, gerig tot die roomse kerk, alle volke en alle mense van 
goeie wil, die verstarde en gevaarlike verdeling van die wêreld in 'n kommunistiese en vrye-demokratiese kamp te versag en om daarmee te toon dat die roomse kerk werklik van hierdie tyd is en nié 'n verstarde, godsdienstige bolwerk wat alleen in herinnering leef nie. Hoewel daar van protestantse kant meer as genoeg bedenkings bestaan teen die agtergronde van hierdie herderlike skrywes is dit wel duidelik dat Johannes XXIII die roomse kerk gedwing het om in direkter bemoeienis met die wêreld te leef ${ }^{3}$ ).

In die derde plek het pous Johannes XXIII deur sy persoonlikheid, wat veral gekenmerk is deur sy innerlike goedheid, daaring geslaag om nie alleen in die roomse kerk groot invloed te kry nie, maar ook buite die kerk het sy persoon gesag en waardering gevind. Dit is grotendeels aan sy invloed te danke dat die roomse kerk wat die protestante vroeër alleen geken het as vervloekte ketters, nou die protestante ecrder as afgeskeie broeders wat ook die erenaam christen dra, tipeer. Deur sy invloed het dit gebeur dat waarnemers uit verskillende protestantse kringe en kerke uitgenooi is om die Konsilie in Rome by te woon waar hulle steeds as dilectissimi observatores (geliefde waarnemers) alangespreek word. Johan nes XXIII het inderdaad op 'n merkwaardige manier daarin geslaag om die roomse kerk 'n groter openheid, 'n vriendeliker gesig na buite toe te gee en dit kan, in die eerste plek, die roomse kark alleen ten goede kom.

Hierdie tweede Vatikaankonsilie wat deur Johannes XXIII geopen is, sal egter nie deur hom afgesluit word nie want op 3 Junie 1963 is hy oorlede. Diarmec het die Vatikaanse Konsilie, wat 'n tydlank verdaag was, ook tot sy einde gekom. Op 21 Junie 1963 is die aartsbiskop van Milaan, Johannes Battista Montini, tot pous gekies en hy dra nou die naam Paulus VI. Die nuwe pous het die vernuwingsbeweging van Johannes XXIII nié afgebreek nie maar dit eerder bevestig en daarom ook bepaal dat die Konsilie weer op 29 September 1963 heropen sal word. Daarby het Paulus VI reeds blyke gegee dat hy ook aan sogenaamde „nuwe teo. logie" in die roomse kerk 'n geleentheid wil gee om sy stem te laat hoor. Om dit te kan bereik het die pous vier kardinale aangewys wat die werk.

1) Lesing gehou by die fees ter herdenking van die Kerkhervorming op 26 Oktober 1963 te Tsumeb, S.W.A.

2) Pous Johannes XXIII se kort regeringstyd word nie oral in die roomse kerk onverdeeld gunstig beoordeel nie want een van die leidinggewende fig'ure in die roomse kerk, kardinaal Siri, het na die dood van die pous geoordeel dat die roomse kerk 50 jaar nodig sal hê om die foute van Johannes XXIII te herstel.

3) Ten opsigte van die ensikliek Pacem in Terris, kan die beswaar veral na vore gebring word dat Johannes XXIII sy ideale vir vrede en orde onder die volke byna volkome baseer op die natuurreg en die gesonde verstand van die mens. Dit is natuurlik moontlik omdat die roomse teologie baie gewig heg aan die gesonde menslike verstand, die natuurreg en die natuurlike moraal. 
saamhede van die konsilie moet lei, al vier manne wat teenoor die ouere, streng behoudende ronmse teologie staan ${ }^{4}$ ). Hieruit word dit wel duidelik dat die roomse kerk van ons tyd deur belangrike bewegings beroer word, ditt na 'n periode van gesletenheid en stilstand onder Pius XII, die roomse kerk weer besef hegin $\mathrm{kry}$ vir die feit dat dic kerk geroep is om herderlike werk in en aan die wêreld te doen, dat dic kerk sc funksic is om die wêreld te dien met en deur die Woord van God.

Terwyl mens dit alles bedink, kan die vraag miskien gestel word wat dit alles met ons wat kinders van die protestantse tradisie is, te make het. As erfgename van die leer en tradisie van Luther en Calvyn kan ons prinsip:eel nie anders as om afwysend teenoor dic roomse kerk te staan nie. Maar tog is daar nog 'n paar ander oorwegings wat na vore kom. As ons bedink dat die roomsc kcrk, dwarsdeur die wêreld, bietjie meer as 400-miljoen lidmate het en dat die gesamentlike getalle van die protestantisme nog nie 200-miljoen is nie terwyl die Islam en die Buddhisme ongeveer 'n 2.300-miljoen navolgers tel. dan is dit duidelik dat die roomse wêreldkerk uit en uit die sterkste enkele godsdienstige gemeenskap van die wêreld is. Daarby is dit miskien interessant om te weet dat die totale getal roomse lidmate in die wêreld byvoorbeeld baie meer is as die getal mensc wat in Sowjet-Rusland woon, sodat folitieke invloed van Rome van ons dag nie sonder betekenis genoem mag word nie. Verder moet ons in ag neem dat Suidelike Afrika al meer en meer aandag van die roomse sending kry en dat daar ook baie duidelike pogings aangewend word om veral die Afrikaner vir dic roomse kerk te wen. In hoeverre dit deel vorm van 'n groter plan om die houvas van die Afrikaanse kerke op die Afrikanervolk te breek, is nou nie hier ter sake nie. In ieder geral is dit we! dudelik dat ons nic sende: meer, sonder in ge belangstelling, dic nuwere verwikkelinge in die roomse kerk kan verbygaan nie.

Juis vanweë hierdie oorwegings is dit van belang om die vraag te stel wat ons, as protestante, van hierdie Konsilie kan verwag. Die menings hicroor loop sterk uiteen - sommige hoop dat daar sterk toenadering sal wees tussen Rome en die protestantisme, ander weer wys, volkome tereg, daarop dat die Tweede Vatikaanse Konsilie 'n interne, roomse aangeleentheid is en dat dic protestantisme eers die uitslag van die Konsilie moet afwag voordat in verantwoorde opinie van protestantse kant daaroor

1) Hulle is die kardinale Agagianian, Lercaro, Doepfner en Suenens. waarvan slegs kard. Agagianian 'n kurie-kardinaal is terwyl die ander drie residerende aartsbiskoppe is. Dit mag, volgens sommige waarnemers, ook daartoe lei dat die konsilie so ver sal kom om die groot mag van die Kurie in Rome enigermate te verminder. Dit moet egter nog gesien word. 
gewaag kan word ${ }^{5}$ ). Die protestantse reaksie van optimisme tot by reserwe en afwysing van die roomse Konsilie mak dit in ieder geval wil noodsaaklik dat ons, as protestante, 'n oomblik ons aandag an hierdie aangeleentheid moet gee.

Met die byeenkoms van hierdie Konsilie in Oktober 1962 en selfs met die openingsrede van pous Johannes XXIII was dit nog nie duidelik wat die tema van hierdie Konsilie sou wees nie. Daar was wel reekse van rapporte van verskillende kommissies wat voor die Kons lie sou dien, maar die sentrale tema waarvolgens àl die studie-materiaal georden moes word, was nog nie aanwesig nie. Dit was die Belgiese kardinaal Suenens wat dic tema voorgestel het wat ook aanvaar is naamlik dat die Konsilie sy hande. linge sou orden na die tema : Oor die Kerk. Hierdie tema moet dan uiteenval in twee groot onderdele t.w.

\section{Wat sê die Kerk oor die Kerk self?}

Onder hierdie hoof sou dan die volgende punte in behandeling geneem word:-

a) die lidmaatskap van die kerk;

b) die bestuursvorm van die kerk -- hier is dit bv. bekend dat baic biskoppe die strak, sentraal-georganiseerde bestuur van die wêreld kerk wat in Rome gekonsentreer is, wil desentraliseer sodat die biskoppe van die kerk 'n groter aandeel sal hê in die regering van die kerk, altyd egter nog onder leiding van die pous;

c) die plek en funksie van die biskop in die kerk;

d) die nadere bespreking van die vorm van die godsdiensoefening dit veral omdat die roomse sending sterk gepleit het dat die volkstaal in die erediens van die kerk gebruik moet word. Dit wil egter voorkom asof hier nie veel verandering in sal kan kom nie omdat Johannes XXIII reeds besl's het dat Latyn dic kerklike taal sal bly;

e) die vervulling van die sendingopdrag van die kerk.

\section{Die Kerk na buite gerig.}

Onder hierdie groot afdeling word dan weer in twee onder-afdelings onderskei nl.

a) die gesprek van die Kerk met die wêreld omdat die wêreld verwag dat die kerk die groot probleme van hierdie tyd, moet help oplos. Hieronder word dan veral verstaan die opvatting van die lewe; 
dic onskendbaarheid daarvan; die geweldige bevolkingsaanwas van die wêreld en watter probleme dit hv. ten opsigte van voeding en derglike meer skep; die sosiale geregtigheid; die besondere evangelisasie van die armes en die groot vrae van oorlog en vrede. Dic bedoeling van dic roomse kerk in hierdie verband word mis. kien die beste weerspieel in die woorde van kardinaal Gerlier:

\begin{abstract}
„Aan hiérdie wêreld, wat ten gronde gaan aan ontdekkings wat die wêreld eerder moes bevry en groter gemaak het, aan hierdie wêreld wat meer en meer ontevrede word namate die wêreld goedere ophoop wat geen bevrediging kan gee nie, moet die kerk die getuienis van die evangeliese armoede uitdra".
\end{abstract}

b) die ekumeniese gesprek met die Grieks-Ortodokse, die Engelse Anglikaanse Kerk en die protestantse kerke, dit is die gesprek met dié broeders met wie die roomse kerk nie sigbaar een is nie.

Of die 2,500 biskoppe wat te Rome onder voorsitterskap van Paulus VI byeen is, inderdaad al hierdie probleme sal kan bespreek en daaroor beslissings sal neem, moet nog eers gesien word. Dit is goed moontlik dat die biskoppe enkele, pertinente vraagstukke na vore sal haal en ander weer agterwee sal laat - dat die Konsilie dus ò die inwendige vernuwing kragtig ter hand sal neem of eerder die probleme na buite sy ernstige aandag sal gee. In watter rigting die finale besluite van die Konsilie ookal mag lê, duidelik is dit wel dat 'n nuwe, dinamieser gees in die kcrk van Rome vaardig geword het en dat die roomse kerk na die Tweede Vatikaanse Konsilie nie heeltemal dieselfde sal wees as daarvoor nie.

Die vraag bly natuurlik in hoeverre hierdie Tweede Vatikaanse Konsilie ons protestante sal raak. Die feit dat die roomse kerk onder Johannes XXIII 'n veel groter belangstelling ook vir die protestantisme gekry het en dat Paul VI die rigting wat hier ingeslaan is, wil voorsit, het in bepaalde protestantse kringe hoë verwagtings ten opsigte van die Kon. silie gewek. Die gedagte is geopper dat 'n baie nouer samewerking tussen die roomse kerk en die protestante, ook op die sendingvelde van die wêreld, nà die Konsilie moontlik sal wees. Dit wil egter voorkom dat hierdie verwagting miskien te optimisties is ${ }^{6}$ ). Die rede daartoe is seker in die eerste plek dat die bedoeling van die Tweede Vatikaansc Konsilie primêr is die eie, innerlike vernuwing van die roomse kerk. Dit gaan vir

5) Hoewel die konsilie aangekondig is as 'n ekumeniese konsilie moet daar geen misverstande as gevolg van hierdie woord ontstaan nie. Volgens die roomse Corpus Iuris Canonici, can. 222-229 is 'n ekumeniese konsilie 'n vergadering van al die biskoppe van die kerke wat deur die pous byeengeroep word en wat onder sy voorsitterskap plaasvind. Dit is dus nie 'n samekoms van die hele christelike kerk nie. 
die kerk hier om 'n interne aangeleentheid, 'n vernuwing van die kerk temidde van die christelike en nie christelike wêreld warin die roomse kerk moet lewe en werk. Die Konsilie wil, volgens die aankondiging van Johannes XXIII, die gloric en luister van die roomse kerk opnuut weer in hierdie wêreld ontvou. dit stel in die taal van hierdie ty dsodat die nie-roomse christendom en die heidendom, bekoor en oorwin deur die boodskap van Rome, sal wens om opgeneem te word in die skoot van die roomse kerk. Juis omdat die roomse kerk die wêreld waarin hy sy boodskap moet uitdra, so goed as moontlik wil ken, daarom het dic roomse kerk kontak gesoek met die nie-roomse christendom sodat dic roomse kerk sy boodskap aan hulle kan oordra in 'n taal wat hulle sal verstaan en sodat hu!le daardeur getref sal word. Rome se belangstelling in die protestantisme en sy soek na die gespreksgeleentheid met die protestantisme en sy scek na die gespreksgeleentheid met die protestantisme is nie blcot terwille van inter-kerklike kontakte nie mar terwille van dic roomse kerk self ${ }^{7}$ ).

Afgesien daarvan dat Rome se aandag met die Tweede Vatikaansc Konsilie primêr na binne, na die roomse kerk sèlf, gerig is, is dit ook nodig dat ons die woorde van die franse kardinaal Bea nie sommerso sal vergeet nie. Want kardinaal Bea het onlangs weer gestel da tdie kerk van Rome nooit meer 'n dogma wat eenmal afgekondig is, kan herroep nie. Immers Rome maak daarop aanspraak dat hy die Heilige Gees onfeilbaar besit en dit beteken dat as die protestante Rome sou vra om hepaalde roomse leerstellings soos byvoorbeeld dié dat die pous van Rome onfeilbaar is, of dié in verband met die sentrale posisie van Maria in die roomse verlossingsleer, te herroep dat Rome dit nie kan doen sonder om homself op te hef nie. Juis dit maak 'n werklike gesprek met Rome byna onmoontlik. Want dit kan nou nie meer 'n gesprek wees waar beide deelnemers aan die gesprek sáám op soek is na die waarheid nie. Rome meen dat hy die waarheid besit en al wat van die protestant verwag word is om hom deur Rome te laat oortuig dat dic Kerkhervorming van die sestiende een 'n fout was, 'n eensydige oorbeklemtoning. Rome kan van die protestant in 'n gesprek prinsipieel niks minder eis as dat hy sy geloof wat op die Heilige Skrif gefundeer is, sal loën en sal terugkeer na die kerk van Rome nie. Inderdaad sal Rome bereid wees om te erken dat Rome in die verlede ook foute gemaak het. Kardinaal Rusch van Oostenryk het in dic jongste tyd nog gestel:

6) Hier is dit wel nodig om Rome se prinsipiële opvattings ten opsigte van die ander christene goed te ken. 'n Goeie samevatting hervan word gevind by: $\mathrm{H}$. van der Linde, Rome en de Una Sanct, , Nijkerk 1948, blz. $122 \mathrm{vg}$ :

7) Vgl. in hierdie verband: K. Barth, Gedachten over het Tweede Vaticaanse Consilie, artikel in Woord en Dienst, Jrg. 12, No. 17, Dell Haag 1963, blz. 273. 


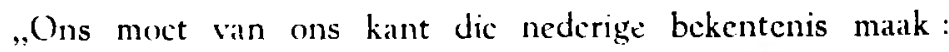
ons het baie dinge verkeerd gedoen. Vier eeue lank het ons slegs aan onsself die waarheid meegedeel, nou moet ons bereid wees om dic waarheid in die taal van ander mense te verkondig".

Rome is wel bereid om foute te erken, maar Rome kan nooit erken dat hy die waarheid, wat van God is, verkeerd geken of gcleer het nie. Selfs pous Johannes XXIII, wat soveel gedoen het vir die openheid van die roomse kerk, het op hierdie punt nie anders gedink nie. Met die opening van sy Konsilie het Johannes XXIII die Konsilie van Trente wat in 1545 gcopen en in 1563 gesluit is en wat in sy besluite 'n vervloeking uitgespreck het oor die vernaamste lcerstellings van die protestantisme, as 'n model voorgehou aan die Tweede Vatikaanse Konsilie. Verder moes elke biskop wat deelneem aan die huidige Konsilie 'n lang lys van leerstellinge van die roomse kerk andermaal onderskryf waaronder ook die veroordeling van Trente van die protestantse regverdigingsleer asook die leerstellings van die Eerste Vatikaanse Konsilie van 1870 dat die pous onfeilhaar is ${ }^{8}$ ).

In ieder geval indien 'n gesprek tussen Rome en die protestante sou plaasvind vanweë en miskien na die Konsilie, dan is dit wel duidelik dat ons alleen vanuit Sondag XXX (Vraag en Antwoord 80) van die Heirelbergse Kateg'smus die gesprek met Rome kán vocr, iangesien Rome ook niks van wat reeds gesê is terug kan neem nie.

Die feit dat die Tweede Vatikaanse Konsilie dic moontlikheid van in gesprek steeds sterker na vore bring. dat daar tog in die soomse kerk in moontlikheid is om terwille van die gesprek 'n groter buigsaamheid ten opsigte van die protestantisme te openbaar as wat die formele lecrstellinge onderskrywing deur die deelnemers aan die Konsilie sou laat vermoed ${ }^{9}$ ). mak dit ook nondsaaklik dat ons 'n comblik sal sien na dit wat ons van Rome skei en wat dan ook die onderwerp van die gesprek tussen die protestante en Rome sou moet wees. Hier sal inderdaad 'n reeks van vraagstukke aan die orde moct kom. Omdat dit egter nie moontlik is om in hierdie hestek alles te behandel nie, word hier slegs twee punte genocm. Dic eerste is ongetwyfel dic vraag na die bron van die waarheid en die tweede is die protestantse leerstuk van die regverdiging deur die geloof alleen.

s) Vgl. Joh. Dreyer, Een en Ander oor dis Konsilie van Trente, artikel in Die Hervormer, Jrg. LIV, No. 6, Krugersdorp 1963, bls. 16.

1) Vgl. hier K. Barth, a.w., blz. 274 asook die geskrif van die roomse teoloog Hans Küng, Kirche in Konzil, Herder Bucherei-Pocket. Bd. 140, Freiburg 1963. 


\section{OOR DIE BRON VAN DIE WAARHEID.}

Die reformatoriese vadere het in die voetspoor van Martin Luther baie duidelik gestel dat die enigste en die afdoende bron van die waar. heid van God en sy openbaring die Heilige Skrif alleen is. Dit het direk ingegaan teen die opvattings van die roomse kerk in hierdie verband. Daarom het die Konsilie van Trente, 1545 - 1563, in sy poging om die roomse leer skerp en duidelik teenoor die protestantisme te definieer dat die roomse kerk langs die Heilige Skrif die oorlewering of tradisie as 'n gelykwaardige bron van die waarheid beskou. Reeds hier, by die verstaan van die Godsopenbaring in Jesus Christus, het Rome 'n plus ten opsigte van die protestantisme en hierdie verskil het sulke verreikende gevolge dat dit al die mees sentrale verskilpunt tussen Rome en die Reformasie genoem is ${ }^{10}$ ).

Die roomse opvatting wil die gesag van die Heilige SSkrif nié verminder nie, inteendeel hulle hou óók daaraan vas dat die hele Skr'f geinspireer is. Maar langs die Skrif is daar die ongeskrewe oorlewering wat in die roomse kerk bewaar gebly het en wat deur hulle ook as 'n bron beskou word waaruit God geken kan word. Hierdie oorlewering is dus nie net daar om die Heilige Skrif nader te verklaar nie, maar dit gee ook gegewens wat die mens nodig het om te weet vir sy saligheid. gegewens wat nie in die Skrif voorkom nie. ${ }^{11}$ ). So is byvoorbeeld die sewe roomse sakramente, die leer van die vagevuur, die leer oor Maria, wat as mede-verlosseres naas Jesus Christus in die roomse kerk vereer word, gebaseer op gegewens wat voortkom uit hierdie mondelinge oorlewering of tradisie wat nié in die Heilige Skrif te vinde is nie. Hoewel die Heilige Skrif in die roomse kerk miskien effens hoër gewaardeer word as hierdie oorlewering, word die gesag van die Heilige Skrif egter heeltemal ondergrawe deurdat die roomse kerk op die Eerste Vatikaanse Konsilie vasgestel het dat die waarheid van die Skrif en die oorlewering nie direk vir die gelowige toeganklik is nie. Die gelowige moet die waar. heid van God soos dit in die Heilige Skrif en die oorlewering gegee is. op gesag van die kerk glo. Tussen die gelowige en die watheid sta:n dus die kerk met sy gesag en in die roomse kerk is al die gesag van die kerk in die figuur van die roomse pous gekonsentreer. Dit beteken dit slegs die pous die Heilige Skrif en die tradisie kan uitlê en verklaar, die gewone gelowige kan dit nié doen nie en terselfdertyd as dic pous

10) Vgl. G. C. Berkhouwer, De Strijd om het r.k. Dogma, Kampen z.j.

11) Ignatius Klug, Het Katholieke Geloof, Heemstede 1939, blz. 444: Over de $H$. Schrift als het geïnspirerende boek van de goddelijke Openbaring hebben we hier niet te spreken, maar weI over het feit, dat volgens de katholieke opvatting narst de $H$. Schrift ook nog de overlevering als geloofsbron moet worden beschouwd. Op blz. 445 word gestel: De $H$. Schrift is uit de Overlevering voortgekomen, doordat een deel van de Overlevering schriftelijk is vastge'egd. 
die Skrif en die oorlewering uitgelê het dan moet die gewone gelowige dié uitleg aanvaar en glo as die enigste korrekte ${ }^{12}$ ).

Daarteenoor het Martin Luther in die sestiende eeu reeds die Heilige Skrif alleen na vore gehaal as die enigste bron van dic waarheid en daarby geleer dat elke gelowige direk, sonder enige menslike bemiddeling toegang het tot die waarheid van die God in die Heilige Skrif. Juis die beklemtoning van hierdie beginsel het die roomse kerk tot in sy fondamente geskud en dit is tot vandag toe een van die kardinale stellings van die kerke van die hervorming. Die beroep op en die gebruikmaking van dic Heilige Skrif alleen vir die geloof en lewe van die mens het in die geloofsleer en praktyk van die kerke van die hervorming 'n geweldige vereenvouding ten opsigte van Rome meegebring 13). Die belangrike punt wat deur die reformatoriese vadere ingehamer is, was dat die Heilige Skrif in homself duidelik en deursigtig is vir elkeen en dat die Heilige Skrif 'n innerlike gesag het wat ons oortuig dat dit die Woord en Waarheid van God is wat ons aanspreek ${ }^{14}$ ). Dit het meegebring dat die Heilige Skrif weer sentraal geplaas is in die lewe van die kerk en die enkele gelowige, dat die altaar afgebreek is en vervang is deur die preekstoel, dat dic pricster vervang is deur dic predikant. dat die onmondige lidmaat van die roomse kerk vervang word dcur dic priesterskap van elke gelowige en dat die Woord van God op dié manier weer op elke huistafel geplaas is. 'n Hele reeks roomse leerstcllings het ook uit die protestantse geloofsbelydenisse verdwy'n en die Bybels-reformatoriese teologie in sy geheel is ' $n$ aanklag teen Rome se opratting dat daar naas die Heilige Skrif nóg 'n bron sou wees wat ook aan dic mens die inhoud cn die waraheid van die Godsopenbaring betuig.

Hierdie kwessie van Skrif én Oorlewering wat tussen die kerke van die hervorming en Rome staan, dateer uit die tyd van die kerkhervorming. Dit word die eerste maal direk deur Luther verkondig as hy stel dat die pous en die konsilies van die roomse kerk nié onfeilbaar is nie, maar alleen dic Woord van God. Daarom het Luther hom teenoor die pous en die hele roomse kerk telkens weer beroep op die gesag van die Heilige Skrif alleen. Dat Rome wel gemerk het dat Luther hier 'n kardinale roomse stelling aanval én ontsenu, blyk wel daaruit dat hulle hom dán ook dreig met die ban en die ewige vervloeking ${ }^{15}$ ).

12) Ignatius Klug, a.w., blz. 444: De naaste geloofsregel is dus het kerkelijk leergezag, de meer vemvijderde geloofsregel wordt gevormd door de bronnen der Openbaring: $H$. Schrift en Overlevering.

Vgl. ook A. F. N. Lekkerkerker, Rome en $R^{n}$ formatie, artikel in $D c$ Reformatie in de Crisis, Wageningen 1949, blz. $177 \mathrm{vg}$.

13) Vgl. hier W. J. Kooiman, Luther en de Bijbe:, Baarn z.j., blz. 15 vg

14) Vgl. Nederlandse Geloofsbelydenis, arts. V, VI, VII.

15) A. F. N. Lekkerkerker, a.w., b]z. 180. 
As ons vandag vanuit die kerkhervorming 'n gesprek met Rome sou voer, dan sal so 'n gesprek seker hiér moet begin want as dit gebeur sal mecste van dic groot verskilpunte tussen Rome en die Reformasie vanself op die agenda verskyn. Die gróót verskil in die leer moet juis terug. gevoer word na die feit dat Rome langs dic Heilige Skrif 'n verdere bron van die warheid aanvaar het wat die protestantisme nic sal of kan erken nie.

\section{OOR DIE REGVERDIGING DEUR DIE GELOOF ALLEEN.}

Tog is met die aanduiding van die verskil in opvatting ten opsigte van die bron van die waarheid, die verskil tussen die reformasie en Rome nog nie teruggevoer na sy diepste verskilpunt nie. Want die nuwe wat Mart $n$ Luther van Wittenberg in dic sestiende eeu na vore gebring het was méér as net die beklemtoning daarvan dat die Heilige Skrif alleen ,die wil van God volkomelik bevat en dat alles wat die mens moet glo om gered te word, daarin genoegsaam geleer word" ${ }^{11}$ ). Immers die mees sentrale wat Luther gestel het, was terselfdertyd die sentrale boodskap van die Brief aan die Romeine en dit is dat die regverdige uit die geloof en nie vanwëe sy werke nie, sal lewe.

As monnik en as priester het Luther by dic Middeleeuse roomsc teoloë geleer dat die geregtigheid van God beteken dat God die mens se goeie werke beloon en die mens se sondige dade straf. Met ander woorde dat in die laaste instansie die mens self verantwoordelik daarvoor is of hy die ewige heerlikheid of verdoemenis ingaan. Oor die mens op aarde staan die laaste oordeel waar die regverdige God die goed en die kwaad sal beloon. Hierdie gedagte het Luther, wat homself met groot strengheid geoordeel het en in homself niks goeds kon vind nie, tot die diepste neerslagtigheid gedryf en nêrens in die roomse teologie kon hy enige rus vir sy gemoed vind nie.

$\mathrm{Na}$ jarelange studie van die Heilige Skrif het hy egter by die bestudering van die Brief aan die Romeine en die Psalms tot die ontdekking grekom dat die geregtigheid van God dit is dat die Here God ons mense vanweë die Kruis en die Opstanding van Jesus Christus, die geregtigheid wat ons nie het nie uit genade skenk. Met ander woorde die geregtigheid van God beteken nie net dat God regverdig is nie maar ook dat $\mathrm{Hy}$ die mens regverdig maak. Hierdie geloofskennis uit die Heilige Skrif het Luther verlos uit sy angste en hom dié troos gegee warna hy gesoek het. 'n God wat aan die mens, om Jesus Christus ontwil, die geregtigheid skenk is nié 'n vreesaanjaende God waarvoor die mens moet vlug nie,

16) Nederlandse Geloofsbelydenis, art. VII. 
maar dit is 'n barmhartige God wat ons met dic geregtigheid ook dic saligheid van dic hemel skenk ${ }^{1-}$ ).

Met hierdie ontdekking het Luther weer opnuut verstaan wat die Bybel bedoel met die woorde genade, geloof en regverdiging. So en daarmee het Luther die breuk geslaan in die ronmse leersisteem en teenoor die roomse kerk die kardinale Bybelse stelling onherroeplik in die sentrum geplaas nl. dat die regverdiging van die mens uit die geloof alleen is ${ }^{18}$ ).

Die roomse leer hieroor, destyds èn vandag, is van 'n heeltemal ander aard omdat dáár die Kruis van Jesus Christus uit sy sentrale plek in die geloof verdring is deur die mens wat beskou word as mede-werksaam met God om die verlossing te verkry. Want in die roomse kerk staan vas dat die mens nie volkome verdorwe deur die sonde is nie en daarom instaat is om goeie werke te doen warvoor hy van God loon sal ontvang. Die mens moet dus sy regverdiging voor God verdien en die ewige heil hang daarom ook van die mens en sy werksaamheid af ${ }^{19}$ ). Hierdie opvatting hang salam met dic roomse visic van die genade wat in goddelike krag is wat aan die mens gegee word, 'n goddelike werking waardeur die mens geleidelik ' $n$ kind van God gemaak word ${ }^{20}$ ). Die mens se lewe is dus 'n voortdurende beweging, 'n opklim in die rigting van die volmaakte heiligheid wat die mens self, met behulp van Gods genade, sal kan bereik. Die mens word dus, volgens hierdie opvatting geleidelik vromer en heiliger en klim so geleidelik self op na so 'n toestand waar hy volkome regverdig en heilig voor Gods aangesig is ${ }^{21}$ ).

By Luther word die genade volkome anders, op grond van die gegewens van die Heilige Skrif, waardeer en word die genade gesien as Gods genadige ges ndheid, 'n vrymagtige daad van God waarin Hy die mens vryspreek van sy sonde. Hierdie daad van God is ' $\mathrm{n}$ daad waarin God die sondaar annecm tot sy kind en dan is dic sondaar ook 'n kind van God. Hierdie vergewing van die sonde, hierdie reguerdig-mak van die mens is egter nie 'n éćnmalige gebeurtenis wat aan die beginpunt van 'n proses staan nie, maar dit is 'n steeds herhaalde ontvang van die vergewing van die sonde. In hierdie daad van God is dic Woord warmee God dic mens aanspreek van die allergrootste belang want van hierdie Woord van God, van hierdie regverdig-verklaring van die mens hang die hele heil van dic mens af. Dáárom raak Luthce ock nooit moeg daarvan om

17) Vgl. hier o.a. K. Holl, Die Rechtfertigungslehre in Luthers Vorlesw1! iibor den Römerbrief 1 sw., artikel in Gesummelte Aufsätze zur Kirchengeschichte, Tübingen 1932, Bd. I, S. 111.

ii) A. F. N. Lekkerkerker, a.wo, blz. 196.

19) Ignatius Klug, a.w., blz. 296 en ook 298: Alleen doo: de zamenwerking van Christus $\in \mathrm{n}$ den mens is de subjectieve deelname aa' $\mathrm{d}_{2}$ verlossin: mogelijk.

20) Vgl. Ignatius Klug, a.w., blz. 293, 299, 307 en $496 \mathrm{vg}$.

21) Ignatius Klug, a.w., blz. 307 . 
van die regverdigmaking van die mens, die vergewing van die sondes te praat nie. En die vergewing is nié die beginpunt van 'n lang proses wat deur die mens se medewerking met die genade van God op die volmaaktheid en die heiligheid uitloop nie, maar 'n vrymagtige daad van God wat die sondaar-mens vanweë die Kruis van Jesus Christus, tot regverdige verklaar. Inderdaad weet die Hervormers ook van 'n lewe van die mens maar dit bly tog so dat selfs die ,allerheiligstes maar 'n klein beginsel van hierdie gehoorsaamheid het solank hulle in hierdie lewe is" $2:$ ). Daar, om praat Luther ook altyd van die gelowige as tegelyk sondaar, tegelyk regverdige.

Hierdie vreemde vryspraak van die sondige mens om Jesus Christus ontwil, dit moet die mens glo en ook by die woord en begrip geloof, kom die verskil tussen Rome en die Reformasie weer sterk na vore. Want geloof is by Rome die verstandelike aanvaarding van die leer van die kerk, die geloof is die middel waardeur die mens hom oopstel na God toe om die heiligmakende genade van God te ontvang. Die geloof is dus nié wesensbelangrik nie, dit is slegs die middcl wararcleur die mens die genade kan ontvang. By die Hervormers, daarenteen, is geloof die middel waardeur die mens elke dag van sy lewe die vergewing van de sondes, wat hy van God ontvang, aanvaar en daarom kom die protestantse gelowige gedurende sy hele lewe nooit verder as die geloof nie. Die latere kerkvader H. F. Köhlbrugge het dit so omskry'we ${ }^{23}$ ).

„By hierdie regverdiging word die mens geen heiligheid ingegiet nie; nee, nee! As 'n goddelose word hy vrygespreek. Die mens verskyn nooit anders voor die genadetroon as 'n goddelose nie, daarom het hy, as 'n goddelose, gedurende sy hele lewe, die vergewing van die sondes nodig, nooit en nimmer sien die mens by homself (goeie) werke wat voor God sou kan tel nie".

Só groot is die afstand hier tussen die Hervorming en die roomse kerk dat dit eintlik nie verbasend is dat die roomse kerk by die Konsilie van Trente die ewige vervloeking uitgespreek het oor almal wat leer dat die goddelose deur die geloof alleen regverdig word (canon 9); dat die genade waardeur die mens geregverdig word, bestaan in d:e genadge gesindheid van God (canon 11); dat die regverdigende geloof niks anders is as die vertroue op die goddelike genade, wat om Christus wil, die sonde vergewe en dat hierdie vertroue alleen genoeg is om ons te reg. verdig (canon 12) ${ }^{24}$ ).

"1.2) Heidelbergse Kategismus, Sondag 44, Vr. en Ant. 114.

2:3) H. F. Köhlbrugge, Uitleggingen over den Brief van Jacobus, Utrecht 1887, blz. 16 (my vertaling). In die bostaande uiteensetting is ook gebruik gemaak van A. F. N. Lekkerkerker, a.w., blz. 196-196.

24) Conciliorum Oecumenicorum Decreta, Freiburg 1962, p. 655. Vgl. ook. decretum de justificatione, p. 647 sg. 
Hier, by hierdie twee behandelde punte, naamlik die totaal ver. skillende opvattings oor die bron van die waarheid van Gods openbaring in die regverdiging van die sondaar voor God, lê die essensie van die verskil tussen Rome en die Hervorming. Die verskil in opvatting ten opsigte van die kerk, die sakramente, Maria, en al die ander verskille sal aangeroer moet word as hierdie twee sake in 'n gesprek met Rome op die agenda geplaas word.

Tot in 'n hoë mate bly dit egter 'n vraag of dit enige sin het om vanuit die protestantisme 'n gesprek met Rome te voer want dic afstand is geweldig groot. In uitgangspunt en uitwerking ten opsigte.van die verstaan van Gods Openbaring in Jesus Christus is daar byna geen punte waar dic Hervorming en Rome dieselfde sê en dieselfde bedoel nie. Sou dit dus beteken dat ons moet volhard by die oordecl van die Heidelbergse Kategismus dat die roomse mis, die hart van die roomse godsdiensoefening, niks anders as ,vervloekte afgodery" is nie? Enersyds sal ons volmondig daarin moct toestem omdat ons nie anders kan as om op grond van die Heilige Skrif alleen die leer van Rome te sien as ' $\mathrm{n}$ verwerplike vermenging van die Goddelike en menslike, hemelse en aardse elemente, 'n verwarring van ewigheid en tyd wat aan die mens nie die heil verkondig nie mar die mens in 'n valse gerustelling inlok en weglei van die sentrum van die Openbaring van God, nl. Jesus Christus, die Gekruisigde en Opgestane Heer ${ }^{2 x}$ ). Tog kom daar dan nog 'n volgende konsiderasie by en dit is dat terwyl Rome dwalende is, dit beteken dat Rome vir ons 'n objek word van evangelisasie, aan wie met klem dic waarheid van die Heilige Skrif, die regverdiging deur die geloof alleen, verkondig moet word. En vanuit hierdie gesigspunt sal die gesprek met Rome, terwyl die protestantse standpunt onverkort gehandhaaf word, wel gevoer kan word. Maar dan sal die gesprek onherroeplik 'n sterk verkondigende karakter moet hê en juis hier sal ons 'n geopende oog moet hê vir die veranderings in die roomse kerk self. Dit is hier waar die Tweede Vatikaanse Konsilie andermaal belangrik word vir ons protestante en dan veral op dié punt dat met die opening van die Konsilie, op 'n duidelike-sigbare plek, die Bybel neergelê is, so dat elkeen dit kon sien. Dit was nie bloot toevallig nie want die merkwaardige is dat die Bybel in die laaste jare weer met ywer en vrug in die roomse kerk gelees word. Dit moet onherroeplik beteken dat Jesus Christus, dic Herc, baie sterker op die voorgrond moet tree in die roomse teologie ${ }^{26}$ ). Dit is veral bemoedigend aangesien mens al meer en meer die indruk gekry het dat die roomse kerk miskien nog wel die kruis besit maar dat hulle die Gekruisigde, soos $\mathrm{Hy}$ in die Heilige Skrif geopenbaar word, verloor het.

25) Vgl. K. Barth, Kirchliche Dogmatik, Zürich 1945, Bd. 1/2, S. 337 ff en $421 \mathrm{ff}$.

(6) K. Barth, Gedarhten, blz. 274. 
Hoewel uit die vernude aandag vir die Heilige Skrif self, in die roomse kerk, seker nie te veel gevolgtrekkings gemaak mag word nie ${ }^{27}$ ), moet in gedagte gehou word dat hierdie bestudering van die Heilige Skrif reeds op die Tweede Vatikaanse Konsilie sy invloed uitgeoefen het. En terwyl ons as protestantse miskien bevrees is dat ons met ons evangelisasie en woorde Rome nooit sal kan oortuig van die verkeerdheid van sy weë nie, dan moet ons nie vergeet n c dat die Woo-d van God self magtig is om groot en radikale veranderinge te mak. Hoewel die spreke van die Woord van God in die roomse kerk versper word deur die dogmas oor Maria, die mede-verlosseres, dié van die onfeilbaarheid van die pous en dergelike meer, was en is die vertroue dat die Woord van God sterker is as alle mense versperrings wat daarteen opgerig word, nog nooit sinloos nie.

- Dit beteken dat ons protestante wel met reserwe sal staan teenoor ! ierdic Tweede Vatikaanse Konsilie en da tons voorlopig niks meer sal kan doen as $\mathrm{cm}$ ons eic standpunt, gebaseer op die walarheid van die Woord van God, teenoor Rome te handhaaf nie. Tog sal ons die gang van sake in die Konsilie bly volg want netsoos Rome vandag anders oor die protestante oordeel, sal ons ook nie altyd Luther se oordeel dat die pousdom dic verpersoonliking van die Antichris is, onverkort wil handhaaf nie. Ten opsigte van Rome sal ons die pogings wat hierdie dwalende broeders aanwend om in hierdie Konsilie tot venuwing van die roomse kerk te kom, met simpatie kan gadeslaan en bly hoop dat dit nog eenmaal in die roomse kerk so ver sal kom dat die Woord van God dáár ook as die enigste bron van die waarheid in gehoorsaamheid en dankbaarheid beluister sal word. Want as kerke wat tevourskyn geroep is deur die magtige, skeppende spreke van die Woord van God, Jesus Christus, onse Here, bly ons al ons heil van dié Woord verwag.

2i) K. Barth, a.w., blz. 274, waarsku nadruklik teen 'n te optimistiesi waardering van hierdie tendens in die roomse kerk. ,Er is geen reden voor wie ook te dromen dat de rooms-katholieken nog eens evangelisch zullen worden in de betekenis die wij daaraan hechten, morgen niet en overmorgen niet en op welke tijdstip ook. 